\title{
Tendencje rozwojowe zgrzewania łukiem wirującym $w$ aspekcie zastosowań w przemyśle motoryzacyjnym
}

\author{
Development direction for magnetically impelled \\ arc butt welding in the automotive industry
}

\section{Streszczenie}

W artykule przedstawiono możliwości wykorzystania zgrzewania łukiem wirującym w przemyśle motoryzacyjnym. Scharakteryzowano ideę i aspekty teoretyczne procesu. Opisano zgrzewanie wybranych materiałów inżynierskich. Przedstawiono rozwój zgrzewania łukiem wirującym na świecie i zestawiono to $z$ warunkami krajowymi. Zaprezentowano trendy rozwojowe zgrzewania łukiem wirującym w aspekcie zastosowań w przemyśle motoryzacyjnym. Opisano możliwości metody podyktowane rozwojem metod numerycznych. Przedstawiono także możliwości rozwoju metod badań nieniszczących połączeń zgrzewanych łukiem wirującym.

\section{Wstęp}

Wprowadzono wiele metod doczołowego spajania materiałów, m.in. spawanie (gazowe, łukowe elektryczne, laserowe), zgrzewanie (doczołowe iskrowe, doczołowe zwarciowe, prądami wysokiej częstotliwości, FSW, tarciowe) i wiele innych. Każda z wymienionych metod ma wiele zalet, ale zazwyczaj technologicznie oraz ekonomicznie ograniczona jest pod względem kosztów czy też wymiarów do określonych zastosowań. Przemysł motoryzacyjny do łączenia elementów konstrukcyjnych półosi i wałów napędowych wykorzystuje głównie zgrzewanie tarciowe. Dynamiczny rozwój stopnia

Dr inż. Tomasz Piwowarczyk, mgr inż. Aleksandra Małachowska, mgr inż. Paweł Sokołowski - Politechnika Wrocławska.

\section{Abstract}

This paper presents actual knowledge about Magnetically Impelled Arc Butt (MIAB) welding and possibility of application this method in the automotive industry. The conception and theoretical aspects of this process were characterized. This method enables joining of many combinations of materials therefore the article describes possibility of welding selected engineering materials. The development of MIAB welding in the world was analyzed and was compared with its expansion in Poland. The trends in terms of application of Magnetically Impelled Arc Butt welding in the automotive industry were presented. In the article were described also the opportunities associated with the development of numerical methods. The development of non-destructive test methods for MIAB welded joints was presented.

automatyzacji, metod badań nieniszczących oraz systemów obliczeń numerycznych spowodował w ostatnim czasie znaczący wzrost zainteresowania konkurencyjną metodą zgrzewania łukiem wirującym.

\section{Aspekty teoretyczne zgrzewania łukiem wirującym}

Zgrzewanie łukiem wirującym jest technologią spajania, w której ciepło niezbędne do otrzymania trwałego połączenia dwóch elementów uzyskiwane jest w wyniku jarzenia się łuku elektrycznego, wprowadzonego magnetycznie w ruch obrotowy $[1 \div 3]$. Łuk elektryczny nadtapia powierzchnie czołowe zgrzewanych elementów i po wywarciu docisku spęczającego w końcowej fazie procesu uzyskiwane są powtarzalne, pozbawione niezgodności złącza. 


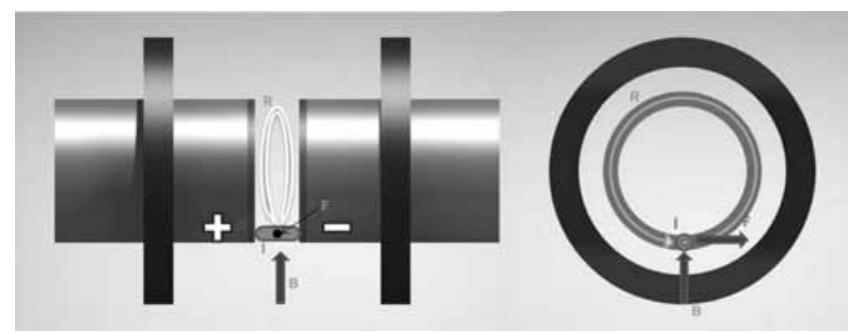

Rys. 1. Oddziaływanie pomiędzy łukiem elektrycznym i przyłożonym polem magnetycznym [6]

Fig. 1. Interaction between electric arc and applied magnetic field

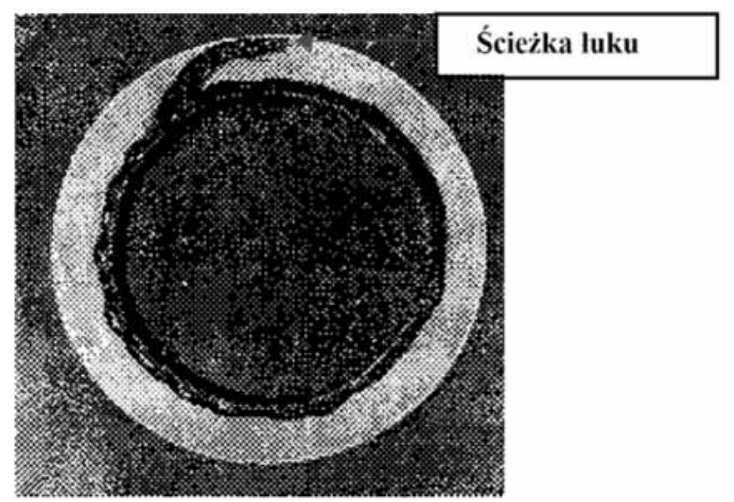

Rys. 2. Ścieżka łuku przemieszczającego się w początkowej fazie procesu do krawędzi wewnętrznej [5]

Fig. 2. Arc trace shows movement to internal diameter in the initial phase of process [5]

Wirowanie łuku jest efektem działania siły Lorentza, powstającej w rezultacie interakcji łuku z polem magnetycznym, generowanym przez cewki lub magnesy trwałe, umieszczone wokół zgrzewanych elementów (rys. 1). Siła ta wyrażona jest równaniem $\mathrm{F}=\mathrm{K} \times \mathrm{I} \times \mathrm{B}$, gdzie: $\mathrm{K}$ - współczynnik zależny od wielkości spoiny (długości łuku), I - wektor natężenia prądu łuku, B wektor indukcji elektromagnetycznej. Kierunek jej działania jest zgodny $z$ regułą lewej dłoni Fleminga. Z powyższych rozważań wynika, że prędkością wirowania łuku, dochodzącą nawet do $200 \mathrm{~m} / \mathrm{s}$ (zwykle prędkość obrotowa $R=600 \div 800$ obr/s), można sterować przez zmianę natężenia pola magnetycznego, wielkości prądu lub szerokości szczeliny $[4 \div 6]$.

W początkowej fazie wirowania, w przypadku materiałów ferromagnetycznych, łuk jarzy się po wewnętrznej średnicy, by w miarę wzrostu temperatury przemieścić się w kierunku strony zewnętrznej (rys. 2). Jest to spowodowane wcześniejszym osiągnięciem temperatury Curie (żelazo przestaje być ferromagnetykiem) przez wewnętrzną stronę rury i tym samym poszerzeniem szczeliny magnetycznej oraz zmianą układu linii pola magnetycznego. Zjawisko to pozwala na równomierne nagrzanie całej ścianki elementu. Mimo to, aby osiągnąć dobre rezultaty zgrzewania, ścianka nie powinna być szersza niż szerokość plamki katodowej łuku $[4 \div 6]$.

Ostatecznie proces zgrzewania łukiem wirującym przebiega $w$ następujących etapach (rys. 3) $[1 \div 3$, $6 \div 10]$ :

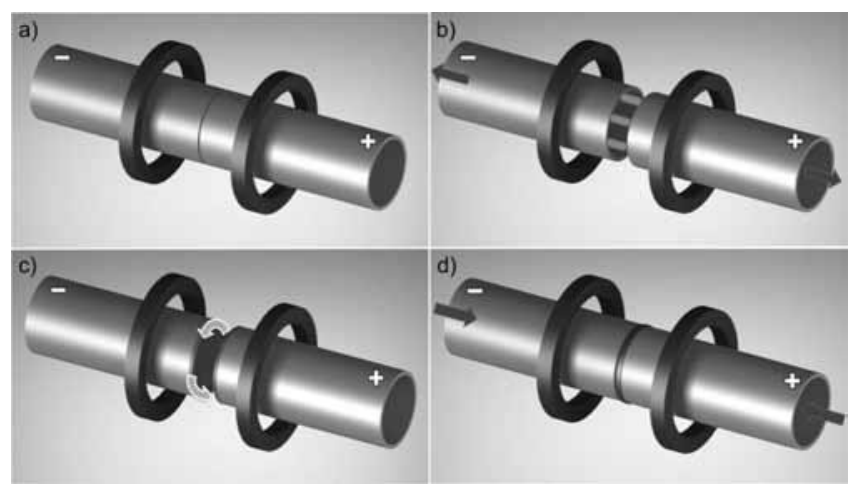

Rys. 3. Etapy zgrzewania łukiem wirującym

Fig. 3. Stages of Magnetically Impelled Arc Butt Welding

a) zamocowanie przedmiotów w szczękach, zetknięcie powierzchni czołowych, nałożenie i wzbudzenie cewki/cewek magnetycznych,

b) odsunięcie przedmiotów, zajarzenie łuku,

c) ruch wirowy łuku, nagrzanie powierzchni łączonych,

d) wywarcie docisku spęczania, wyłączenie prądu, ewentualna obróbka cieplna.

Konieczne jest spełnienie wielu czynników, aby proces przebiegał stabilnie, a otrzymane złącza charakteryzowały się odpowiednimi właściwościami użytkowymi. Do najważniejszych parametrów zgrzewania należy zaliczyć [1, 11]:

- natężenie prądu łuku - decyduje przede wszystkim o szybkości nagrzewania powierzchni łączonych oraz szerokości strefy, która ulegnie stopieniu. Wraz z jego wzrostem zwiększeniu ulega obszar ciekłego materiału, natomiast zmniejsza się czas zgrzewania i w konsekwencji szerokość SWC. Dobór odpowiedniej wartości natężenia prądu łuku jest ściśle związany z kolejnym parametrem - odległością pomiędzy powierzchniami czołowymi łączonych elementów (rys. 4a) [11]. Operator zgrzewarki ma możliwość ustawienia tzw. stałego przebiegu prądu (duże natężenie, krótki czas) lub stopniowanego przebiegu prądu (początkowo mniejsze natężenie, które w końcowej fazie mocno wzrasta - $w$ pierwszym etapie nadtopienie powierzchni może powodować zalewanie szczeliny). $\mathrm{W}$ zależności od wymiarów łączonych elementów oraz rodzaju materiału wartości natężenia prądu mogą wynosić $0,1 \div 2,7 \mathrm{kA}[1]$.

- szerokość szczeliny pomiędzy powierzchniami łączonych materiałów - dobór szerokości szczeliny związany $\mathrm{np}$. ze zgrzewalnością materiałów lub mocą zgrzewarki powoduje konieczność zmiany większości parametrów procesu, w szczególności natężenia prądu łuku. Wraz ze wzrostem odległości łączonych przedmiotów zwiększa się zapotrzebowanie na prąd, natomiast w momencie przekroczenia możliwości prądowych źródła proces staje się niestabilny. $Z$ drugiej strony, zapewnienie odpowiednich parametrów szczeliny i prądu łuku powoduje prawidłowe jarzenie się łuku, równomierne nadtapianie powierzchni, a także zminimalizowanie 

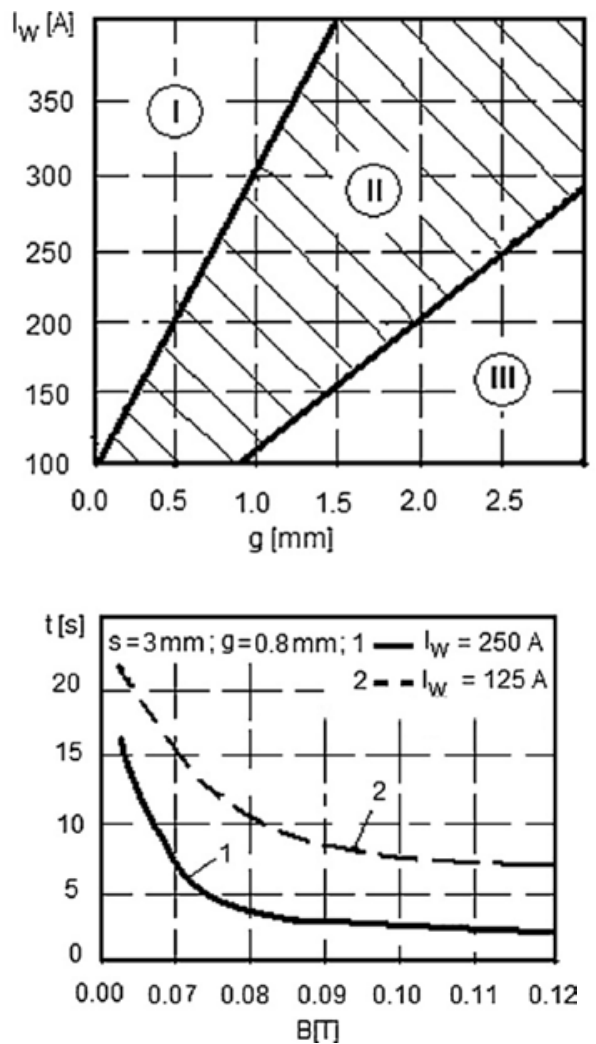

Rys. 4. Przykładowe charakterystyki technologiczne procesu: a) diagram stabilności procesu, charakterystyka natężenia prądu łuku $w$ funkcji szerokości szczeliny między materiałami $I_{w}(g)$ : I i III - obszar wygaszania łuku, braku obrotu łuku lub jarzenia się niestabilnego łuku, II - obszar prawidłowego jarzenia i obrotu łuku; $\mathrm{b}$ - czas trwania procesu w zależności od natężenia pola magnetycznego $t(B): I_{w}$ - natężenie prądu łuku, $A$; $B$ - natężenie pola magnetycznego, $\mathrm{T} ; \mathrm{g}$ - szczelina pomiędzy elementami, $\mathrm{mm}$; $\mathrm{s}$ - grubość łaczonych elementów, mm; $\mathrm{t}$ - czas zgrzewania, $\mathrm{s}$ [11]

Fig. 4. MIAB welding characteristics: a) stability of the process, welding current intensity as a function of tubes gap value $I_{w}(g)$ : I, III - areas of unstable rotation of arc, short lifetime of arc or without arc rotation, II - area of high quality arc initiation and very stable rotation; b) welding time as a function of magnetic field $t(B)$ : $\mathrm{I}_{\mathrm{w}}$ - welding current, $\mathrm{A} ; \mathrm{B}$ - magnetic field, $\mathrm{T} ; \mathrm{g}$ - welding gap, $\mathrm{mm}$; $\mathrm{s}$ - elements thickness, $\mathrm{mm} ; \mathrm{t}$ - welding time, $\mathrm{s}$ [11]

prawdopodobieństwa pojawienia się zwarć. Dla większości elementów łączonych obecnie metodą zgrzewania łukiem wirującym stosuje się szerokość szczeliny w zakresie $1,5 \div 3,5 \mathrm{~mm}$ [1];

- prąd wzbudzenia cewek magnetycznych oraz natężenie pola magnetycznego - gdy zapewnimy stałą wartość natężenia prądu łuku oraz odległość pomiędzy powierzchniami czołowymi łączonych elementów, to jedyną możliwością zmiany charakterystyki procesu jest zmiana parametrów pola magnetycznego. Można $w$ ten sposób regulować prędkość wirowania łuku i decydować m.in. o czasie trwania procesu (rys. 4b) [11].

- czas zgrzewania - związany jest bezpośrednio $z$ natężeniem prądu łuku oraz prędkością wirowania łuku. W związku z tym jest to parametr dobierany każdorazowo na podstawie prób eksperymentalnych, w zależności od zgrzewanych materiałów, a)
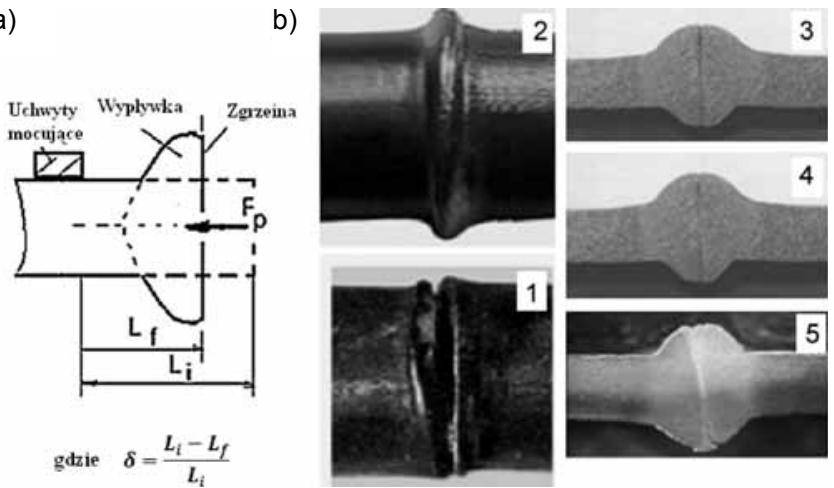

c)

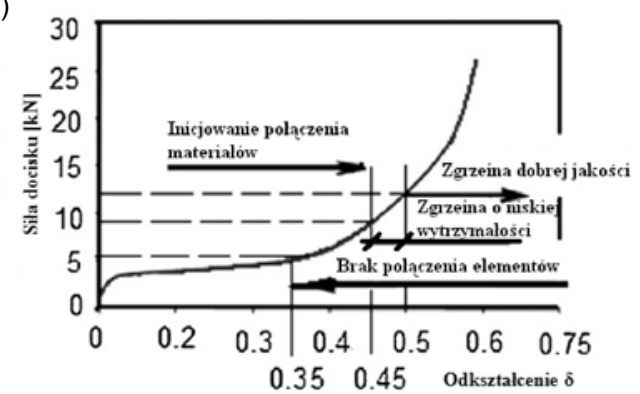

Rys. 5. Proces spęczania materiału zgrzeiny: a) ujęcie schematyczne; b) przegląd zgrzein wraz z makrostrukturami złączy: 1 - elementy niepołączone, 2 - prawidłowe złącze, 3 - zainicjowane połączenie materiałów $\delta=0,45,4-$ zgrzeina o niskiej jakości $\delta=0,5,5$ - zgrzeina wysokiej jakości $\delta=0,55$; c) charakterystyka siły spęczania w zależności od odkształcenia elementów $F_{p}(\delta)$ [11] Fig. 5. The process of upsetting in the final phase of MIAB weIding; a) scheme of the tube wall deformation process; b) examples of welds images and macrostructures: 1 - non-welded elements, 2 - qualitative MIAB weld, 3 - weld initiation by $\delta=0,45,4$ ) low quality joint by $\delta=0,5,5$ - high quality joint by $\delta=0,55$; c) upsetting force as a function of material deformation $F_{p}(\delta)[11]$

kształtu i wymiarów złącza etc. Czas zgrzewania elementów wynosi zazwyczaj: $1 \mathrm{~s}$ dla średnicy $20 \mathrm{~mm}$; $6 \mathrm{~s}$ dla średnicy $50 \mathrm{~mm}$ (kilka - kilkanaście sekund dla stopniowanego przebiegu prądu) [1];

- siłę oraz prędkość spęczania zgrzeiny - powinny spowodować wyciśnięcie na zewnątrz cienkiej warstewki ciekłego metalu wraz z zanieczyszczeniami i zapewnić trwałe połączenie w stanie plastycznym materiałów (rys. 5) [11]. Jeżeli siła spęczania elementów będzie zbyt niska, elementy nie ulegną połączeniu, bądź też uzyskane połączenie będzie charakteryzowało się małymi właściwościami wytrzymałościowymi. Stosowane zazwyczaj siły docisku, w zależności od charakterystyki produkcji, zawierają się w granicach $0,8 \div 40 \mathrm{kN}$ [1].

Czynnikiem dodatkowo poprawiającym jakość uzyskiwanych połączeń jest osłona gazowa. Rodzaj i natężenie przepływu gazu ochronnego zapobiegają występowaniu niezgodności w złączu, ale także wpływają na kształt i rozkład temperatury łuku, prędkość nagrzewania oraz wielkość siły spęczania. Dla stali niskowęglowych, ze względu na krótki czas trwania procesu, nie jest wymagana gazowa ochrona złącza, natomiast dla stali niskostopowych i stopowych stosuje się 
zazwyczaj $\mathrm{CO}_{2}$ o wydatku zależnym od kształtu i wymiarów złącza, a w przypadku stali wysokostopowych konieczne jest użycie jako gazu ochronnego Ar lub He. Jeżeli osłona gazowa nie jest wykorzystywana, stosuje się na ogół krótki impuls wysokoprądowy, aby usunąć zanieczyszczenia przez wyprysk ciekłego metalu [5].

\section{Zgrzewanie wybranych materiałów inżynierskich}

Zgrzewanie łukiem wirującym może być stosowane do łączenia szerokiej gamy materiałów inżynierskich, jednak najlepsze efekty uzyskuje się w przypadku zgrzewania stopów żelaza: stali stopowych, niestopowych, staliw czy żeliw, w związku z czym tego typu połączenia występują najczęściej w warunkach przemysłowych [12]. Możliwe jest również zgrzewanie elementów zahartowanych czy ulepszonych cieplnie, trzeba się jednak liczyć ze spadkiem twardości w strefie wpływu ciepła.

Typowe złącza wykonane za pomocą łuku wirującego mają niewyraźną linię łączenia i wąską strefę wpływu ciepła o drobnoziarnistej strukturze (rys. 6). Przegrzany materiał jest usuwany w postaci wypływki [13].

W przypadku elementów o grubszych ściankach występuje problem przegrzewania obszaru w pobliżu wewnętrznej krawędzi powierzchni łączenia. Wówczas po wewnętrznej stronie może pojawić się struktura gruboziarnista, częściowo nawet w postaci struktury Widmanstättena. Zjawisko to można wyeliminować, kontrolując linię pola magnetycznego i tym samym przemieszczania się łuku z krawędzi wewnętrznej ku zewnętrznej [13].

W przypadku zgrzewania elementów z powłokami, np. chromowanych czy cynkowanych, podstawowym problemem jest zwiększona zawartość materiału powłoki w zgrzeinie powodująca spadek wytrzymałości złącza. Dlatego ważne jest, aby powierzchnie przeznaczone do łączenia pozostały niepokryte. Ilość wtrąceń można również zmniejszyć przez dobór odpowiedniego cyklu prądowego skutkującego zwiększonym wypryskiem i tym samym usunięciem zanieczyszczeń [5, 12].

Pozytywne wyniki uzyskiwane są również przy zgrzewaniu aluminium i jego stopów, przy czym zaleca się umieszczanie elementu aluminiowego jako katody, aby uzyskać efekt czyszczenia katodowego. Ze względu jednak na niższą gęstość pola magnetycznego metali nieżelaznych niż stali stosowane jest niekiedy umieszczanie rdzenia żelaznego w środku zgrzewanych elementów nieżelaznych [5, 14].

\section{Rozwój zgrzewania łukiem wirującym na świecie}

W literaturze anglojęzycznej zgrzewanie łukiem wirującym określane jest jako Magnetically Impelled Arc Butt Welding, w skrócie MIAB. Metoda ta opracowywana w Instytucie Spawalnictwa im. E.O. Patona w latach 50. i 60. została później skomercjalizowana przez firmę Kuka Welding, która określiła ją mianem Magnetarc i pod tą nazwą funkcjonuje obecnie na rynku niemieckim [4].

Szczegółowa analiza wyraźnie wskazuje, że intensyfikacja prac nad tą techniką miała miejsce na przeło-

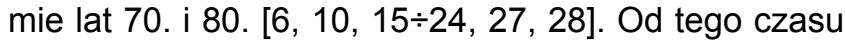
prace naukowo-badawcze nabrały wyraźnego charakteru aplikacyjnego. Na rynku europejskim (Niemcy, Francja), jak również amerykańskim czy japońskim, zgrzewanie łukiem wirującym uzyskało dopuszczenia odpowiednich ośrodków dozoru technicznego i stosowane jest w produkcji wielu odpowiedzialnych konstrukcji, głównie w przemyśle samochodowym.
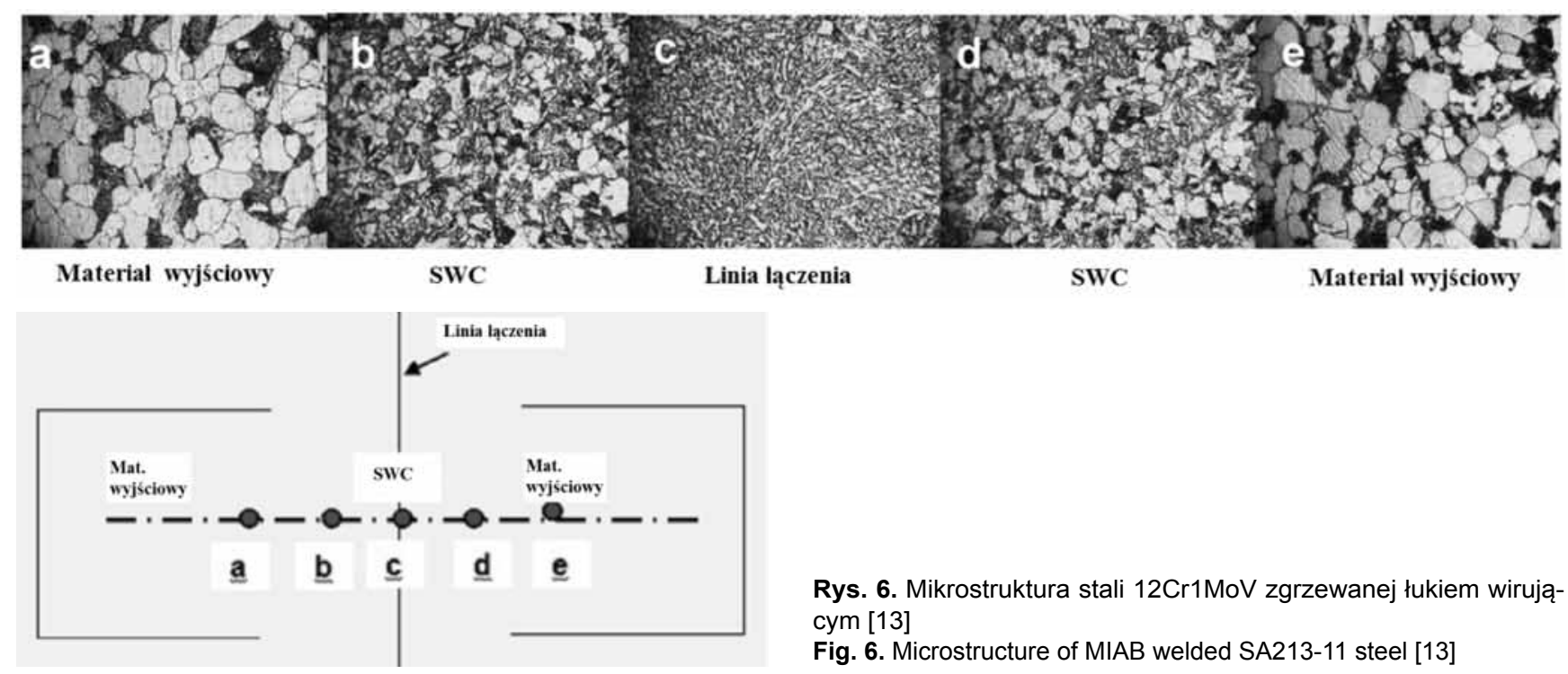

Rys. 6. Mikrostruktura stali $12 \mathrm{Cr} 1 \mathrm{MoV}$ zgrzewanej łukiem wirującym [13]

Fig. 6. Microstructure of MIAB welded SA213-11 steel [13] 
Zagraniczne ośrodki naukowo-badawcze w ostatnich latach zintensyfikowały prace związane $z$ tą technologią. Szczególny nacisk położono na obszary badawcze ukierunkowane na:

- możliwości wykorzystania technologii zgrzewania łukiem wirującym do łączenia materiałów różnoimiennych [29];

- wdrożenie omawianej technologii do łączenia elementów cienkościennych o złożonych, często niesymetrycznych kształtach [29, 30];

- rozszerzenie spektrum materiałów możliwych do połączenia tą metodą, np. wysokowytrzymałych elementów stalowych czy lekkich podzespołów na bazie aluminium i jego stopów [29];

- perspektywy zastosowania technologii zgrzewania łukiem wirującym do produkcji elementów, części maszyn i urządzeń, pracujących w warunkach dużych obciążeń eksploatacyjnych (np. zbiorniki wysokociśnieniowe) [13, 31];

- usprawnienie procesu przez odpowiednie kształtowanie pola magnetycznego z wykorzystaniem różnych systemów magnesowania [11];

- opracowanie systemów monitoringu procesu zgrzewania łukiem wirującym z wykorzystaniem metod nieniszczących w celu zapewnienia odpowiedniego poziomu jakości łączonych elementów [3];

- wsparcie procesu zgrzewania łukiem wirującym metodami numerycznymi, m.in. do określania rozkładów linii pola magnetycznego, określenia sił elektromagnetycznych, analizy przebiegu temperatur podczas procesu etc. [4].

\section{Rozwój zgrzewania łukiem wirującym w Polsce}

Zgrzewanie łukiem wirującym, znane u nas również pod nazwami zgrzewanie łukiem przyspieszonym magnetycznie czy zgrzewanie łukiem wzbudzonym magnetycznie, mimo że znane od drugiej połowy $\mathrm{XX}$ wieku, nie znalazło szerokiego zastosowania praktycznego. Powodem takiego stanu były początkowo skomplikowane, a jednocześnie niegwarantujące wysokiej jakości połączeń urządzenia do zgrzewania, ograniczenia kształtowe do profili zamkniętych czy ograni-

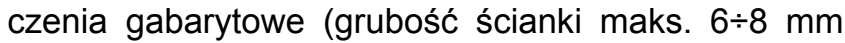
i powierzchnia maks. $3000 \mathrm{~mm}^{2}$ ). Dotychczas w naszym kraju nie było linii technologicznej wykorzystującej ten proces. Jedyne prace o charakterze naukowym w tej dziedzinie prowadził Instytut Spawalnictwa, na stworzonym do tego celu stanowisku badawczym [3, 7, 8]. Intensyfikacja działań prorozwojowych tej technologii w ostatnich latach, głównie w aspekcie metod kontrolnych, stopnia zaawansowania i zautomatyzowania maszyn i urządzeń oraz możliwości technologicznych, spowodowała znaczne zainteresowanie krajowych odbiorców przemysłowych. Prekursorem wprowadzającym na Polski rynek technologię zgrzewania łukiem wirującym jest światowy lider wśród dostawców półosi i systemów napędowych dla przemysłu motoryzacyjnego - firma GKN Driveline.

\section{Trendy rozwojowe zgrzewania łukiem wirującym w aspekcie zastosowań w przemyśle motoryzacyjnym}

Przemysł motoryzacyjny, jak każda inna dynamicznie rozwijająca się branża, dąży do minimalizacji kosztów, przy jednoczesnym podniesieniu jakości produkowanych komponentów. Przedsiębiorstwa produkujące elementy konstrukcyjne samochodów nieustannie dążą do sprostania coraz wyższym wymaganiom, stawianym przez koncerny produkujące auta. W aspekcie części konstrukcyjnych pojazdów oczekiwania odbiorcy dotyczą głównie trzech parametrów: jakości wykonania (związanej z zapewnieniem bezpieczeństwa użytkowników pojazdów), ceny jednostkowej produktu i zdolności realizacji dużych zamówień. Jednym z podstawowych kierunków rozwoju produkcji wałów napędowych jest minimalizacja masy wyrobu. To zaś powoduje stosowanie coraz cieńszych ścianek rur wykorzystywanych w produkcji wspomnianych elementów. Charakterystyka procesu zgrzewania łukiem wirującym sprawia, że jest to technologia bardzo dobrze wpisująca się w obecne trendy panujące w przemyśle motoryzacyjnym, gdzie dzięki stosowaniu materiałów o podwyższonej wytrzymałości i mniejszej grubości dąży się do zredukowania masy nieresorowanej pojazdów. Głównie dlatego producenci układów przeniesienia napędu zastępują w ostatnim czasie stosowaną od lat technologię zgrzewania tarciowego nowoczesnym zgrzewaniem łukiem wirującym (rys. 7). Pomijając korzyści ekonomiczne płynące z tego typu działań, należy pamiętać, że priorytetem nadal pozostaje zapewnienie odpowiedniego poziomu bezpieczeństwa konstrukcji pojazdu. W sytuacji, kiedy zmniejszona zostaje grubość łączonych elementów, coraz większe znaczenie ma konieczność zapewnienia odpowiedniej jakości wytwarzanego elementu. Niebezpieczeństwo pojawienia się niezgodności technologicznych wpływa w znacznym stopniu

a)

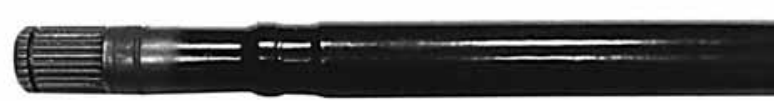

b)

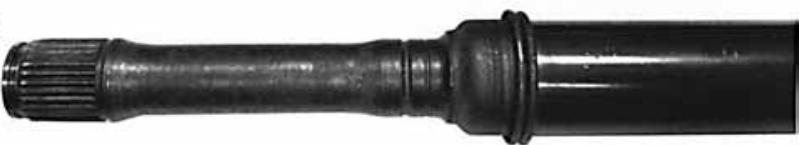

Rys. 7. Porównanie zgrzewania łukiem wirującym: a) po obróbce z konwencjonalnych zgrzewaniem tarciowym, b) zgrzeina nieobrobiona

Fig. 7. Comparison of MIAB process: a) machined with conventional friction welding, b) unmachined weld 
na zmniejszenie efektywnego przekroju zgrzeiny, przez co wyraźnie spadają jej wskaźniki wytrzymałościowe.

Sama technologia łączenia, jak również uzyskane z jej wykorzystaniem złącza wykazują wiele zalet $[1 \div 3$, $7,8,15 \div 24,27,28]$. Zastąpienie zgrzewania tarciowego techniką zgrzewania łukiem wirującym oprócz redukcji masy pojazdu wykazuje wiele innych korzyści w przypadku łączenia elementów wałów napędowych. Siły wzdłużne potrzebne do zgrzania elementów metodą tarciową powodują zbyt duże deformacje detali o tak cienkich ściankach i powodują bicie promieniowe na nieakceptowalnym poziomie. Dzięki zastosowaniu metody MIAB problem ten zostaje zredukowany do minimum. Zgrzewane rury mogą być chromowane w celu wyeliminowania negatywnych skutków erozyjnego oddziaływania specjalnych płynów. Dodatkową zaletą jest oszczędność czasu (średnio o 10\%) przy odpowiednio dobranych parametrach łączenia. Nie bez znaczenia jest również czynnik ekonomiczny, będący efektem np. mniejszego zapotrzebowania na moc $(5 \div 10 \%$ mocy zgrzewania zwarciowego, iskrowego lub tarciowego). Zalety te skłoniły do implementacji zgrzewania łukiem wirującym liczne firmy $z$ branży motoryzacyjnej, w tym Thyssen Krupp Automitive System, czy Ford Motor Company, w których po zoptymalizowaniu parametrów i przeprowadzeniu niezbędnych badań proces został z sukcesem wdrożony do produkcji masowej [27, 28]. Elementy i podzespoły wytwarzane z wykorzystaniem zgrzewania łukiem wirującym to oprócz wałów i półosi: oprawy łożysk, absorbery energii, tuleje, zbiorniki ciśnieniowe, katalizatory, pokrywy zaworów, łączniki, wahacze, filtry, wlewy paliwa i wiele innych.

\section{Możliwości wynikające z rozwoju metod numerycznych}

Potwierdzeniem dynamiki rozwoju techniki zgrzewania łukiem wirującym jest zastosowanie metod MES do jej wspomagania (rys. 8) [4]. Przy użyciu metod symulacyjnych możliwe jest przeprowadzenie wielu użytecznych analiz. Dzięki symulacji wielkości generowanego ciepła przez wirujący łuk elektryczny oraz przepływu ciepła w łączonych elementach możliwe jest sprawdzenie, czy dane parametry prądowe będą wystarczające do stopienia wybranych materiałów i uzyskania poprawnego złącza. W podobnym celu modelowana i sprawdzana jest również siła spęczania elementów. Praktyczne rezultaty dają również analizy numeryczne parametrów pola elektrycznego i magnetycznego. Są one wykorzystywane przy wszelkiego rodzaju modyfikacjach elementów odpowiadających za ich wzbudzenie, zajarzenie łuku oraz wymuszenie jego ruchu po powierzchniach czołowych łączonych elementów. Przy użyciu nowoczesnych systemów MES można obecnie symulować tak złożone procesy jak możliwość zajarzenia łuku, czy zweryfikować jego prędkość. Możliwość szybkiego sprawdzenia tak szczegółowych zjawisk przyczyniła się do zoptymalizowania
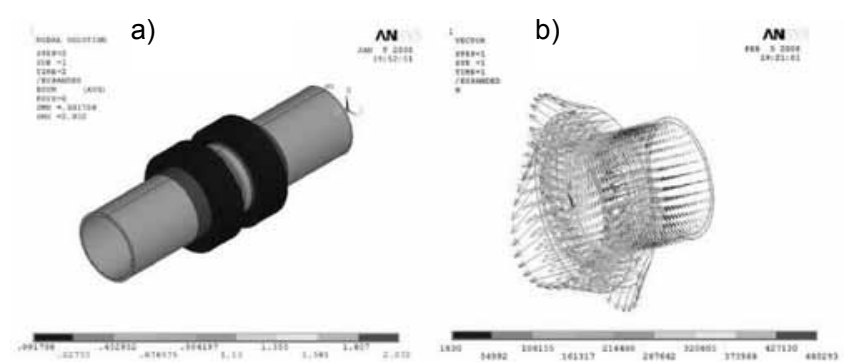

Rys. 8. Przykład zastosowania MES do symulacji parametrów procesu zgrzewania łukiem wirującym: a) model dyskretny, b) rozkład siły elektromagnetycznej w obszarze zgrzewania [4]

Fig. 8. Example of FEM application for simulation of welding process parameters for MIAB welding: a) finite element model, b) electromagnetic force distribution in the welding area [4]

procesu zgrzewania łukiem wirującym i wzrostu zainteresowania tą metodą. Rezultatem wspomnianych analiz było m.in. zastosowanie w zgrzewarkach kompleksowego systemu magnesowania, opartego na zwielokrotnieniu liczby cewek magnetycznych (w klasycznych systemach są stosowane pojedyncze cewki) [11].

\section{Rozwój metod badań nieniszczących połączeń zgrzewanych łukiem wirującym}

Od kilku lat technologia zgrzewania łukiem wirującym jest stopniowo wdrażana do produkcji w wielu zakładach produkcyjnych w całej Europie. O ile sama technologia wykazuje wiele wspomnianych już zalet w porównaniu z konwencjonalnymi metodami doczołowego łączenia rur, o tyle problematyka kryteriów szybkiego odbioru złączy zgrzewanych wymaga prac optymalizacyjnych. Procedury wdrażania technologii zgrzewania łukiem zazwyczaj są oparte na doświadczeniach danego koncernu. Mimo planowanego przepływu wiedzy i doświadczeń proces kontroli jakości połączeń jest niesatysfakcjonujący i wymaga usprawnienia. Jednym z przewidywanych kierunków rozwoju techniki zgrzewania łukiem wirującym będą prace zmierzające do stworzenia dodatkowej komórki linii produkcyjnej, automatycznie i w bardzo krótkim czasie weryfikującej poprawność wykonanych złączy. Jeśli planowany system sprostałby założeniom produkcyjnym, mógłby zostać wdrożony w wielu zakładach, a wtedy wyniki zyskałyby oddźwięk na skalę europejską. Ciągłe dążenie do zmniejszania stanów magazynowych, a co za tym idzie zmniejszania partii produkcyjnych powoduje konieczność częstego (nawet kilkakrotnego w ciągu jednego dnia) przezbrajania produkcji. To zaś powoduje konieczność zatwierdzenia poprawności procesu dla każdej pierwszej produkowanej sztuki. Obecnie używane metody sprawdzania poprawności procesu zgrzewania tarciowego zajmują do $40 \mathrm{~min}$. Przez ten czas linia produkcyjna jest 


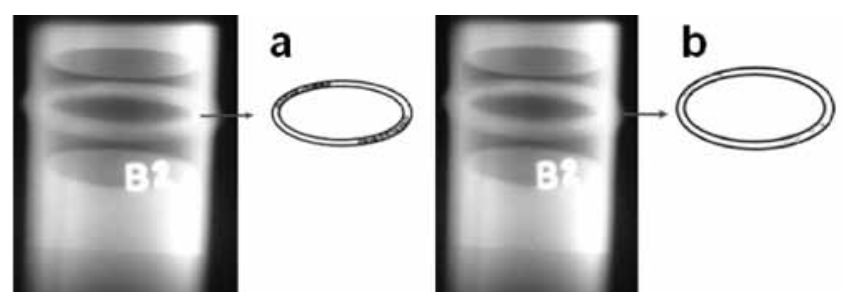

Rys. 9. Przykładowe badania radiograficzne połączeń wykonanych zgrzewaniem łukiem wirującym, a - zgrzeina nieobrobiona, b - zgrzeina szlifowana i polerowana [30]

Fig. 9. Exemplary X-ray examination of MIAB welded joint, $a-$ unmachined weld, $b$ - grinded and polished weld [30]

wstrzymywana z powodu weryfikacji wyników badań laboratoryjnych. Skracając ten czas o kilkadziesiąt minut przez wprowadzenie metod nieniszczących, m.in. badań ultradźwiękowych czy radiograficznych (rys. 9) [31], można uzyskać znaczne oszczędności roboczogodzin pracy zgrzewarki w skali roku i spożytkować je na produkcję. To daje kilkuprocentowy wzrost wydajności bez inwestycji w nowe urządzenie wytwórcze. Na przykład tylko 30- minutowa redukcja czasu przezbrajania produkcji przekłada się na oszczędność 360 godzin rocznie, co odpowiada $6 \%$ wzrostowi wydajności. Jest to wynik nieosiągalny żadnymi innymi modyfikacjami procesu produkcyjnego, nawet z wykorzystaniem najbardziej zaawansowanych narzędzi jakościowych.

Oprócz wyżej wymienionych, wyniki badań ukierunkowanych na poszukiwanie metodologii oceny jakości złączy zgrzewanych łukiem wirującym mogą generować dla producentów półosi i wałów napędowych złożone korzyści. Przede wszystkim gwarantują kwalitatywny, stabilny, powtarzalny i efektywny proces wytwarzania. Mogą być jednak równie pomocne do oceny jakości wyrobów podczas zmiany parametrów zgrzewania czy adaptacji linii technologicznej do innych komponentów. Każde przezbrojenie linii produkcyjnej na inny wyrób wymaga zatwierdzenia poprawności wykonania operacji przed uruchomieniem produkcji danej serii. Najwięcej trudności przysparza zatwierdzanie procesów realizowanych w wysokich temperaturach, a zatem wpływających bezpośrednio na zmiany strukturalne materiału, np. wybranych metod spajania (spawanie, zgrzewanie, lutowanie) czy obróbki cieplnej (hartowanie). Wymaga to każdorazowo testów niszczących i analiz laboratoryjnych. Niestety takie badania są bardzo absorbujące, a co za tym idzie wydłużają czas procesu uruchomienia produkcji po przezbrojeniu. Taka sytuacja znacznie pogarsza wydajność linii produkcyjnej i źle wpływa na gospodarkę magazynową. Minimalizowanie liczby przezbrojeń wprawdzie ogranicza ich negatywny wpływ na wydajność procesu, ale niestety zwiększa stany magazynowe zarówno komponentów do produkcji, jak i gotowych wyrobów. Wszelkie skuteczne działania ukierunkowane na szybsze przezbrojenia przynoszą bardzo łatwo wyliczalny zysk dla przedsiębiorstwa. Zatem stworzenie uniwersalnego stanowiska badawczego zapewniłoby znaczne usprawnienie procesu produkcyjnego oraz eliminację problemów występujących podczas przezbrajania linii.

\section{Podsumowanie}

Zgrzewanie łukiem wirującym jest znane stosunkowo długo, jednak z uwagi na znaczny rozwój myśli technicznej, jak i narzędzi inżynierskich w ostatnich latach, dopiero od niedawna obserwujemy znaczący wzrost zainteresowania tą metodą. Dzięki wielu istotnym zaletom jest to technologia bardzo dobrze wpisująca się w wymagania stawiane wyrobom wytwarzanym w przemyśle samochodowym. Warunki narzucone przez branżę motoryzacyjną, dotyczące zarówno wysokiej jakości elementów, jak i kosztów oraz czasu wytwarzania powodują, że głównym problemem staje się obecnie zapewnienie szybkiej kontroli jakości produkowanych podzespołów. Zaadaptowanie wybranych metod badań nieniszczących może pozytywnie wpłynąć na stopień zapewnienia jakości wytwarzanych wyrobów, a tym samym przyczynić się do wzrostu zainteresowania zgrzewaniem łukiem wirującym światowych potentatów środowiska motoryzacyjnego.

\section{Literatura}

[1] Klimpel A.: Spawanie zgrzewanie i cięcie metali - Technologie, WNT, Warszawa, 1999.

[2] Pilarczyk J. (red.): Poradnik Inżyniera Spawalnictwo, t. 2, WNT, Warszawa, 2005.

[3] Kubiszyn I.: Zbadanie warunków zgrzewania łukiem wirującym. Praca badawcza Instytutu Spawalnictwa, nr Ba-37. Gliwice 1980.
[4] Arungalai Vendan S., Manoharan S., Buvanashekaran G., Nagamani C.: Development of a MIAB welding module and experimental analysis of rotational behavior of arc-simulation of electromagnetic force distribution during MIAB welding of steel pipes using finite element analysis, The International Journal of Advanced Manufacturing Technology, 2009, 43.

[5] Sato T., Katayama J., loka S., Otani M.: An experimental study of rotational behaviour of the arc during magnetically impelled arc butt welding, Welding International, 1991, 5 (1), 5-10. 
[6] Ganowski F. J.: The magnetarc welding process. Welding \& Metal Fabrication, 1974, vol. 42, no. 5, s. 206-213.

[7] Lassociński P.: Podstawy teoretyczne zgrzewania łukiem wirującym. Przegląd Spawalnictwa, 1992, nr 1, s. 2-6.

[8] Lassociński P.: Urządzenia do zgrzewania łukiem wirującym. Przegląd Spawalnictwa, 1993, nr 1, s. 12-16.

[9] Linnert G.E.: Welding metallurgy - carbon and alloy steels. AWS, Miami, Florida, 1994. Ed. 4, vol. I. Fundamentals. Chapt. 6, s. 515-517.

[10] Gerlach M.: Stand und Entwicklungsrichtungen des MBL-HVerfahrens. ZISMitt., 1981, Bd. 23, no. 10, s. 1124-1129.

[11] Iordachescu D., lordachescu M., Georgescu B., Miranda R.M., Ruiz-Hervias J., Ocana J.L.: Technological windows for MIAB welding of tubes featuring original longitudinal magnetization system with peripheral solenoids, Journal of Materials Processing Technology 2010, 210.

[12] Merkblatt DVS 2934, Preßschweißen mit magnetisch bewegtem Lichtbogen (MBP-Schweißen), 2001.

[13] Arungalai Vendan S., Manoharan S., Nagamani C.: MIAB welding of alloy steel tubes in pressure parts: Metallurgical characterization and nondestructive testing, Journal of Manufacturing Processes, 2012, 14.

[14] Mori S., Yasuda K.: Magnetically impelled arc butt welding of aluminum pipes, Welding Inernational 1989, no. 11, s. 941946.

[15] Gratz H.J.: Erfassung von Parametern beim MBL-Schweissen zur Gutesicherung. ZISMitt., 1979, Bd. 21, no. 10, s. 1122-1124.

[16] Hagon D., Riley N.: MIAB welding - Part 2. Fabricating the Fiesta rear axle, Metal Construction, 1979, vol. I I, no. 12, s. 625-629.

[17] Johnson K.I.: MIAB welding - principles of the process. Metal Construction, 1979 , vol. II, no. 11, s. 590-597.

[18] Johnson K.I.: The magnetically impelled arc butt welding of mild steel tubing. Welding Journal, 1979 , vol. 58 , no. 11 , s. 17-27.
[19] Krohn H.: Automatisches Kehlnahtschweissen - mit dem MBL-Verfahrenkein Problem. ZIS Mitt., 1979, Bd. 21, no. 10, s. $1101-1104$.

[20] Loebner R.: Magnetarc welding theory and practice. Doc. MIS III-694-81.

[21] Paasch M.: Leistungssteigerung durch den Einsatz von MBL-Vorrichtungen. ZISMitt., 1979, Bd. 21, no. 10, s. 11051109.

[22] Pening E.: MBL-Schweissen an abnahmsopflichtigen Bauteilen im Kraftwerk-anlagenbau. ZISMitt., 1979, Bd. 21, no. 10, s. $1110-1114$

[23] Penning F.: MBL-Schweissen bei der Fertigung von Bohrgestange. ZISMitt., 1981, Bd. 23, no. 10, s. 1144-1151.

[24] Poetschukat W.: Lichtbogenlaufverhalten beim MBL-Schweissen von Rohr Platte Verbindungen. ZISMitt., 1981, Bd. 23, no. 10, s. $1137-1143$.

[25] Schmidt Hiller, Breiksh: Use of the Magnetarc Welding Process in the Production of Truck Cub Suspension Systems, ThyssenKrupp Techforum, December 2003, s. 40-43.

[26] Hagon D., Riley N.: An industrial Application of MIAB WeIding of Tubes: A Rear Axle Cross Tube Assembly, Second International Conference on Pipe Welding, London, 20-22 November $1979 \mathrm{~m}$, vol. 17 , s. 51-58.

[27] Schlebeck E.: Automatisierungsprobleme der MBL-Schweisstechnik. ZISMitt., 1979, Bd. 23, no. ID, s. 1090-1101.

[28] Takagi K.: Application of rotating arc butt welding to town gas pipelines. Doc. MIS 1II-673-81.

[29] Materiały informacyjne firmy Diverse Technologies: website. lineone.net.

[30] Materiały informacyjne firmyJIT Engineering \& Solutions: www.jitengg.com

[31] Arungalai Vendan S., Subba Reddy Mundla, Buvanashekaran G.: feasibility of magnetically impelled arc butt (MIAB) welding of high-thickness tubes for pressure parts, Materials and Manufacturing Processes, 2012, 27 